\title{
Proton Conductive Inorganic-Organic Hybrid Membranes as an Electrolyte for Fuel Cells Prepared from 3-Glycidoxypropyltrimethoxysilane and Orthophosphoric Acid
}

\author{
Kiyoharu TADANAGA, ${ }^{*}$ Hiroshi YoshIDA, Atsunori MATSUDA, \\ Tsutomu MinAmI, and Masahiro TATSUMISAGO
}

\author{
Department of Applied Materials Science, Graduate School of Engineering, Osaka Prefecture University (Sakai, Osaka \\ 599-8531, Japan)
}

Received June 20, 2002 ; Accepted July 17, 2002

\begin{abstract}
Proton conductive inorganic-organic hybrid membranes were prepared from 3-glycidoxypropyltrimethoxysilane, tetramethoxysilane and orthophosphoric acid by the sol-gel method. The ionic conductivity of the hybrid membranes increased with an increase in the content of orthophosphoric acid in the membranes, and was about $1 \times 10^{-2} \mathrm{~S} \mathrm{~cm}-1$ at $30^{\circ} \mathrm{C}$ under relative humidity of $80 \%$, for the membranes with a molar ratio of $\mathrm{P} / \mathrm{Si}=1.5$. Test cells were fabricated using the hybrid membranes with composite electrodes prepared from the precursor sol of the hybrid membranes and Pt black powders, and these cells were confirmed to work as a fuel cell.
\end{abstract}

Key Words : Inorganic-organic Hybrid, Sol-gel Method, 3-glycidoxypropyltrimethoxysilane, Fuel Cell

\section{Introduction}

Inorganic-organic hybrid materials, where inorganic and organic components are chemically bonded each other, have extensively been studied because blending of organic and inorganic components allows the development of materials with novel properties. " The sol-gel process using alkoxysilanes with organic groups is known to be a practical method for preparing the hybrid materials.

On the other hand, solid materials with high proton conductivity have attracted much attention for the application to a variety of electrochemical devices. ${ }^{2-4)}$ Among these electrochemical devices, polymer electrolyte-type fuel cells (PEFCs) are extensively studied as one of the new energy conversion devices. The present PEFCs operate at temperatures lower than $100^{\circ} \mathrm{C}$ because the proton conductive membranes used for the fuel cells lose their conductivity at temperatures higher than $100^{\circ} \mathrm{C}$. To improve energy conversion efficiency and to avoid $\mathrm{CO}$ poisoning of catalysts, PEFCs which can operate at temperatures higher than $100^{\circ} \mathrm{C}$ are strongly desired. ${ }^{4}$ In addition, due to high production cost of the membranes from perfluoroalkyl sulfonates, a new type of membranes with a lower cost has been required. ") For example, proton conductive inorganic-organic hybrid membranes have been proposed ${ }^{4-11}$ as an alternative to the perfluoroalkyl sulfonates.

We have reported that the preparation of proton conductive solid electrolytes by the sol-gel method, ${ }^{12-19)}$ and very recently we have prepared proton conductive inorganic-organic hybrid membranes, which showed high proton conductivity at temperatures higher than $100^{\circ} \mathrm{C}$ without humidification, from 3-glycidoxypropyltrimethoxysilane (GPTMS), tetramethoxysilane (TMOS) and orthophosphoric acid by the sol-gel method. ${ }^{201}$ The membranes with $\mathrm{P} / \mathrm{Si}$ of 1.5 (molar ratio) kept a high conductivity of about $7 \times 10^{-4} \mathrm{~S} \mathrm{~cm}^{-1}$ even after holding for $6 \mathrm{~h}$ under $0.7 \%$ relative humidity at $130^{\circ} \mathrm{C}$. This indicates that the weight and volume of humidifiers, which are indispensable for the present PEFCs, can be reduced by using the hybrid membranes as an electrolyte.

In the present paper, proton conductivity and chemical durability have been examined for the hybrid membranes with different phosphoric acid contents. Test cells were fabricated using the hybrid membranes with composite electrodes prepared from the precursor sol of the hybrid membranes and Pt black powders, and polarization performance was measured for the cells.

\section{Experimental}

GPTMS and TMOS were dissolved in ethanol, and aqueous orthophosphoric acid was added to the solution to hydrolyze the silanes. After being stirred for $2 \mathrm{~h}$, precursor sol was obtained. Molar ratio of GPTMS : TMOS was fixed to be $3: 1$, and the ratio of (GPTMS + TMOS) $: \mathrm{H}_{3} \mathrm{PO}_{4}$ was changed from 0 to 1.5 . The sol was poured into petri dishes and gelled at room temperature. Gel membranes obtained were then dried at $50^{\circ} \mathrm{C}$ for 1 day, and consecutively at $100^{\circ} \mathrm{C}$ for $5 \mathrm{~h}$ and at $150^{\circ} \mathrm{C}$ for $5 \mathrm{~h}$.

Molar ratios of $\mathrm{P} / \mathrm{Si}$ in the hybrid membranes were determined with energy dispersive X-ray analysis. Proton conductivity of the membranes was determined from the impedance data obtained using an impedance analyzer in a frequency range of $10 \mathrm{~Hz}$ to $8 \mathrm{MHz}$.

For the fabrication of a single cell, composite electrodes were formed on both sides of the hybrid membranes which were only dried at $50^{\circ} \mathrm{C}$. The composite electrode was prepared using the precursor sol for the 




Fig. $1 \mathrm{P} / \mathrm{Si}$ molar ratios versus nominal $\mathrm{P} / \mathrm{Si}$ of hybrid membranes as prepared and after being kept at $30^{\circ} \mathrm{C}$ and $60 \% \mathrm{R}$. $\mathrm{H}$. for $3 \mathrm{~h}$ and being immersed in water for $3 \mathrm{~h}$.

membrane and Pt black powders. Precursor sol was separately prepared, and Pt black powders were added to the sol. Since the precursor sol contained ethanol as a solvent, the composite electrodes were easily formed on both sides of hybrid membranes with thickness of about $300 \mu \mathrm{m}$ by painting the sol containing Pt black. Thickness of the composite electrode was about $100 \mu \mathrm{m}$ and $\mathrm{Pt}$ content was estimated to be $0.1 \mathrm{mg} \mathrm{cm}^{-2}$. Active area of the cell was about $16 \mathrm{~cm}^{2}$. Polarization performances were measured at $30^{\circ} \mathrm{C}$ with dry $\mathrm{H}_{2}$ gas at the anode and air with relative humidity (R.H.) of $60 \%$ at the cathode.

\section{Results and Discussions}

Self-supporting, flexible, brownish transparent membranes with a thickness of about 200 to $300 \mu \mathrm{m}$ were obtained in the composition of $\mathrm{P} / \mathrm{Si}=0$ to 1.5 (molar ratio). From the nitrogen adsorption measurements, the hybrid membranes were found to have almost no pores and BET surface areas were estimated to be less than $0.5 \mathrm{~m}^{2}$ $\mathrm{g}^{-1}$, indicating that the membranes were dense.

Figure 1 shows measured $\mathrm{P} / \mathrm{Si}$ molar ratios versus nominal $\mathrm{P} / \mathrm{Si}$ ratio of hybrid membranes (a) as prepared, (b) after being kept at $30^{\circ} \mathrm{C}$ under $60 \%$ R.H. for $3 \mathrm{~h}$ and (c) after being immersed in water for $3 \mathrm{~h}$. Phosphorus was confirmed to be mainly present as isolated phosphoric acid in the hybrid from ${ }^{31} \mathrm{P}$ NMR spectra. ${ }^{201}$ Molar ratios of $\mathrm{P} / \mathrm{Si}$ of the membranes as prepared were consistent with the nominal $\mathrm{P} / \mathrm{Si}$ ratios. Almost all portions of phosphoric acid remain in the membranes after keeping the hybrid membranes in a chamber at $30^{\circ} \mathrm{C}$ under $60 \%$ R.H. for $3 \mathrm{~h}$. However, for the membranes after being immersed in water observed $\mathrm{P} / \mathrm{Si}$ ratios become almost half of the nominal $\mathrm{P} / \mathrm{Si}$ ratios. The immersion of the membranes in water should bring about the leaching of half of phosphoric acid. Since epoxy groups in GPTMS were confirmed to be cleaved under the acidic conditions to form hydroxy groups, hydroxy groups formed must have strong interaction with phosphoric acid, and most of phosphoric acid remained in the membranes after being kept at $30^{\circ} \mathrm{C}$ under $60 \%$ R.H. but the interaction is

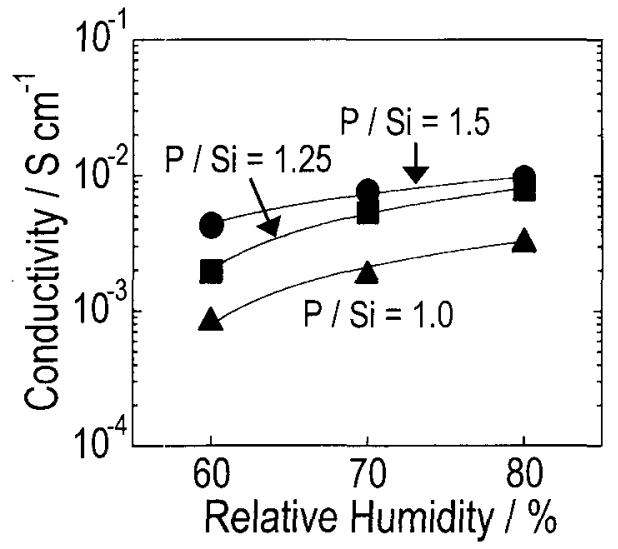

Fig. 2 Proton conductivity of the hybrid membranes as a function of relative humidity at $30^{\circ} \mathrm{C}$.

not strong enough to avoid the leaching of phosphoric acid when immersed in water.

Figure 2 shows proton conductivity of the hybrid membranes as a function of relative humidity at $30^{\circ} \mathrm{C}$. The conductivities of all the hybrid membranes slightly increase with an increase in relative humidity from 60 to $80 \%$, and increase with an increase in the contents of phosphoric acid in the membranes; the conductivity was about $1 \times 10^{-2} \mathrm{~S} \mathrm{~cm}^{-1}$ at $30^{\circ} \mathrm{C}$ under relative humidity of $80 \%$, for the membranes with $\mathrm{P} / \mathrm{Si}$ of 1.5 . These results indicate that the amount of adsorbed water in the membranes must increase with an increase in relative humidity as well as an increase in the contents of phosphoric acid, and water contributes to the increase in conductivity. Although nitrogen adsorption measurements showed that the hybrid membranes had dense structure, paths suitable for fast proton conduction should be formed in the hybrid gel membranes due to the adsorption of water.

Figure 3 shows cell voltage versus current density for a test cell with the hybrid membrane $(\mathrm{P} / \mathrm{Si}=1.0)$ at $30^{\circ} \mathrm{C}$ by using pure dry hydrogen and air of $60 \%$ R.H. at $30^{\circ} \mathrm{C}$. The open circuit potential of the cell is about $0.85 \mathrm{~V}$. This small value is probably due to gas permeation through small pores within the hybrid membranes, or due to gas leakages from the test cell. Fuel cell voltage



Fig. 3 I-V characteristics of a test cell with the hybrid membrane at $30^{\circ} \mathrm{C}$ by using pure hydrogen at the anode and air of $60 \%$ R.H. at the cathode. 
drops with an increase in current density, and a power of about $0.3 \mathrm{~mW} \mathrm{~cm} \mathrm{~m}^{-2}$ is obtained with current density of 1 $\mathrm{mA} \mathrm{cm}^{-2}$. To obtain high performance, a decrease in membrane thickness, an increase in Pt loading, operations at high temperature and high relative humidity are necessary. Nevertheless, the cell performance observed in this study with dry $\mathrm{H}_{2}$ and the ambient air shows high potentiality of inorganic-organic hybrids as an electrolyte and a component of composite electrodes for fuel cells.

\section{Conclusions}

Proton conductive inorganic-organic hybrid membranes were prepared from GPTMS, TMOS and orthophosphoric acid by the sol-gel method. The proton conductivity of the membranes increased with an increase in the contents of phosphoric acid in the membranes. The conductivity for the membranes with $\mathrm{P} / \mathrm{Si}=1.5$ (molar ratio) was about $1 \times 10^{-2} \mathrm{~S} \mathrm{~cm}^{-1}$ at $30^{\circ} \mathrm{C}$ and $80 \%$ R.H. Test cells fabricated using the hybrid membranes and composite electrodes from the precursor sol of the hybrid membranes and Pt black powders demonstrated great potentiality of inorganic-organic hybrids as an electrolyte and a component of composite electrodes for fuel cells.

\section{Acknowledgment}

This work was supported by the Grant-in-Aid for Scientific Research on Priority Areas from the Ministry of Education, Culture, Sports, Science and Technology of Japan.

\section{References}

1) U. Schubert, N. Husing, and A. Lorenz, Chem. Mater., 7, 2010 (1995).

2) K.D. Kreuer, Chem. Mater., 8, 610 (1996).
3) A. Walcarious, Chem. Mater., 13, 3351 (2001).

4) G. Alberti and M. Casciola, Solid State Ionics, 145, 3 (2001).

5) L. Depre, J. Kappel, and M. Popall, Electrochim. Acta, 43, 1301 (1998).

6) L. Depre, M. Ingram, C. Poinsignon, and M. Popall., Electrochim. Acta, 45, 1377 (2000).

7) B. Bonnet, D. J. Jones, J. Roziere, L. Tchicaya, G. Alberti, J.M. Casciola, L. Massinelli, B. Bauer, A. Peraio, and E. Ramunni, J. New Mater. Electrochem. Systems, 3, 87 (2000).

8) U.L. Stranger, N. Groselj, B. Orel, and P. Colomban, Chem. Mater., 12, 2745 (2000).

9) Y. Park and M. Nagai, Solid State Ionics, 145, 149 (2001).

10) Y. Park and M. Nagai, J. Electrochem. Soc., 148, A616 (2001).

11) H. Nakajima and I. Honma, Solid State Ionics, 148, 607 (2002)

12) M. Tatsumisago and T. Minami, J. Am. Ceram. Soc., 72, 484 (1989).

13) M. Tatsumisago, K. Kishida, and T. Minami, Solid State Ionics, 59, 171 (1993).

14) M. Tatsumisago, H. Honjo, $Y$ Sakai, and T. Minami, Solid State Ionics, 74, 105 (1994).

15) A. Matsuda, H. Honjo, M. Tatsumisago, and T. Minami, Chem. Lett., 1998, 1189.

16) T. Kanzaki, A. Matsuda, Y. Kotani, M. Tatsumisago, and T. Minami, Chem. Lett., 2000, 1314.

17) A. Matsuda, T. Kanzaki, Y. Kotani, M. Tatsumisago, and T. Minami, Solid State Ionics, 139, 113 (2001).

18) A. Matsuda, T. Kanzaki, K. Tadanaga, M. Tatsumisago, and T. Minami, Electrochim. Acta, 47, 939 (2001).

19) A. Matsuda, T. Kanzaki, K. Tadanaga, M. Tatsumisago, and T. Minami, J. Ceram. Soc. Jpn., 110, 131 (2002).

20) K. Tadanaga, H. Yoshida, A. Matsuda, T. Minami, and M. Tatsumisago, Chem. Mater, in press. 